\title{
DIGITAL GAME BASED LEARNING UNTUK PEMBELAJARAN ARITMATIKA BAGI PENYANDANG TUNANETRA
}

\author{
Galang Prihadi Mahardhika ${ }^{1}$, Husnul Anwar ${ }^{2}$ \\ Jurusan Teknik Informatika, Fakultas Teknologi Industri, Universitas Islam Indonesia ${ }^{1,2)}$ \\ Jl. Kaliurang Km.14,5, Sleman, Yogyakarta 55501 \\ Email :galang.prihadi@uii.ac.id ${ }^{1}$
}

\begin{abstract}
Visual impairment is a condition that causes one cannot access visual information clearly. Most of people with visual impairment access visual information through the sense of hearing and touch. One of activity which accessing visual information is indispensable is learning activities. Learning activities can affect one's ability to understand and master what they learn. Moreover, in order to make learning activities more interesting, fun learning activities need to be created, such as learning while playing. The activities of learning while playing can be implemented by developing game based learning. This study was conducted to develop a game based learning that can help people with visual impairment to do learning activities for arithmetic subject. The interactivity in the game is a combination of touch and swipe interaction tehniques. From the user acceptance testing, result shows that the game is ease to use and to learn, and has a simple and intuitive interface. The next improvement for this game can be adding other interaction techniques such as hold, double click, multitouch, et cetera.
\end{abstract}

Keywords : Visual Impairment, Fun Learning, Game Based Learning, Aritmetic.

\section{PENDAHULUAN}

Gangguan penglihatan (visual impairment) adalah suatu kondisi yang terjadi akibat hilangnya fungsi indera pelihat yang signifikan dan tidak dapat disembuhkan dengan obat - obatan, operasi bedah, atau alat optik umum seperti kaca mata (Kanyemba et al, 2017). Orang yang menderita gangguan penglihatan disebut dengan penyandang tunanetra. Secara umum, gangguan penglihatan terbagi menjadi dua kategori, yaitu buta total (totally blind) dan penglihatan rendah (low vision). Buta total adalah keadaan dimana seseorang tidak dapat melakukan interaksi secara visual, atau tidak dapat melihat sama sekali, sedangkan penglihatan rendah adalah keadaan dimana seseorang dapat melihat namun dengan keterbatasan tertentu (tidak dapat melihat secara jelas). Berdasarkan data yang didapat dari WHO (World Health Organization), ada sekitar 285 juta orang dengan gangguan penglihatan di seluruh dunia pada tahun 2011, dengan 39 juta orang menderita buta total, dan 246 juta orang menderita penglihatan rendah (Söveny et al,
2014). Sekitar 7\% tunatera di seluruh dunia berasal dari kalangan anak-anak (Jonas, 2014). Meskipun jumlah penderita gangguan penglihatan pada anak sedikit, namun penanggulangan masalah penglihatan pada anak perlu mendapat perhatian khusus karena pada usia dini, seseorang perlu untuk dapat mempelajari berbagai hal yang dibutuhkan bagi kehidupannya.

Gangguan penglihatan dapat mengurangi kualitas hidup seseorang dan keterampilan sosialnya (Kordestani et al, 2014; Sarabandi et al, 2013). Ketrampilan sosial penyandang tunanetra tidak dapat berkembang karena mereka tidak dapat mengoptimalkan interaksi sosial seperti isyarat visual (visual cues), pembuatan pola (pattern making), membaca raut muka (states of face), menerima umpan balik (feedback), dan lain sebagainya. Salah satu dampak dari lemahnya ketrampilan sosial bagi penyandang tunanetra adalah terbatasnya kemampuan mereka untuk dapat melakukan aktivitas sehari - hari (Berger \& Porell, 2008). Penyandang tunanetra dapat memaksimalkan indera pendengar dan 
indera peraba untuk dapat melakukan interaksi (Heuten et al, 2008). Optimalisasi indera pendengar dapat dilakukan dengan memanfaatkan media suara. Berbagai macam informasi dapat dikemas dalam bentuk suara untuk kemudian dapat diakses oleh penyandang tunanetra. Optimalisasi indera peraba dapat dilakukan dalam bentuk perangkat taktil (tactile). Perangkat taktil adalah segala bentuk perangkat yang dapat diraba atau disentuh. Perangkat taktil umumnya digunakan oleh penyandang tunanetra sebagai media penerima dan penyampai informasi. Dengan optimalisasi indera pendengar dan peraba, penyandang tunanetra dapat lebih terbantu dalam melakukan aktivitas sehari - hari.

Salah satu aktivitas yang penting bagi pertumbuhan anak adalah aktivitas belajar (Vogel et al, 1999). Secara normal, proses belajar pada anak dilakukan dengan memanfaatkan semua indera yang dimiliki untuk mengakses semua informasi yang mereka butuhkan. Seorang anak dengan kebutuhan spesial terhadap suatu inderanya perlu mendapatkan dukungan khusus untuk dapat mengakses suatu informasi bagi perkembangan kelimuannya (McAllister \& Gray, 2007). Salah satu upaya yang dapat dilakukan adalah dengan menyediakan sebuah alat yang dapat digunakan sebagai media belajar bagi penyandang tunanetra.

Ilmu pengetahuan terbentuk melalui proses tranformasi pengalaman yang didukung oleh pemahaman yang baik (Kolb \& Kolb, 2005). Salah satu alat yang dapat digunakan untuk meningkatkan pengalaman seseorang adalah permainan. Proses belajar sambil bermain dapat dilakukan melalui pendekatan gim berbasis komputer atau yang biasa disebut dengan game based learning. Proses belajar yang dilakukan dengan menggunakan gim memiliki efek yang signifikan dalam meningkatkan ketertarikan siswa terhadap pembelajaran yang di modelkan (Hussain, 2014), yang berdampak pada peningkatan motivasi belajar siswa ( $\mathrm{La}$ Guardia et al, 2014).
Penelitian ini dilakukan untuk mengembangkan suatu game based learning yang dapat digunakan sebagai media bantu belajar matematika bagi penyandang tunanetra. Matematika adalah salah satu disiplin ilmu yang dapat melatih seseorang untuk berpikir logis dan sistematis dalam memecahkan suatu masalah dan membuat keputusan (Ali, 2017). Kemampuan memecahkan suatu masalah dan membuat keputusan merupakan kemampuan dasar yang harus dimiliki oleh seseorang dalam menjalankan kehidupan, tidak terkecuali bagi penyandang tunanetra. Aplikasi yang dikembangkan pada penelitian ini akan mengangkat materi dasar dalam disiplin ilmu matematika, yaitu aritmatika. Proses pembelajaran matematika dapat ditingkatkan dengan pemodelan yang menarik dan interaktif memanfaatkan aplikasi berbasis komputer (Jonsson et al, 2014). Salah satu aplikasi yang dapat digunakan adalah game based learning (Mahardhika, 2016).

\section{METODOLOGI PENELITIAN}

Penelitian ini dilaksanakan dengan menggunakan model ADDIE (Analyzing, Designing, Developing, Implementing, and Evaluating). ADDIE terdiri dari 5 (lima) tahapan proses, yaitu analisis (Analysis), perancangan (Design), Pengembangan (Development), Implementasi (Implementation), dan Evaluasi (Evaluation) (Tang et al, 2017). ADDIE merupakan salah satu model yang sangat efektif untuk pengembangan alat pendukung proses pembelajaran atau yang juga dikenal dengan istilah CAI (Computer Aided Instruction) (Huang et al, 2005).

\section{HASIL DAN PEMBAHASAN \\ 3.1. Analisis (Analysis)}

Proses analisis dilakukan untuk mengidentifikasi masalah yang diangkat dan mengumpulkan kebutuhan yang diperlukan untuk kemudian dikembangkan menjadi tugas - tugas yang harus dilakukan. Proses analisis dibuat berdasarkan observasi yang dilakukan di SLB Yaketunis (Yayasan 
Kesejahteraan Tuna Netra Islam). Berikut adalah analisis yang dihasilkan :

a. Hasil observasi :

1. Materi yang diajarkan tidak jauh berbeda seperti materi sekolah pada umumnya, yang membedakan adalah cara serta media yang digunakan untuk menyampaikan materi tersebut.

2. Sekitar $80 \%$ siswa SLB Yaketunis telah terbiasa menggunakan perangkat ponsel pintar (smart phone) berbasis Android untuk kebutuhan belajar (mengakses informasi) dan berkomunikasi.

3. Alat bantu ajar berbasis Android belum banyak digunakan di SLB Yaketunis.

4. Salah satu jenis aplikasi yang ditemukan para perangkat Android adalah aplikasi cerdas cermat dengan interaksi pilihan ganda. Namun sebagian besar aplikasi tersebut tidak didesain khusus untuk penyandang tunanetra.

5. Warna yang dapat dilihat oleh penyandang tunanetra dengan penglihatan rendah (low vision) adalah warna dengan tingkat kontras yang tinggi dengan sedikit kombinasi warna, seperti hitam - putih, merah tua - kuning muda, biru tua - putih, dan lain - lain.

b. Analisis kebutuhan :

1. Model game based learning berbasis Android untuk membantu proses pembelajaran aritmatika bagi penyandang tunanetra.

2. Materi yang akan digunakan sebagai obyek belajar siswa.

3. Model interaksi yang sesuai untuk penyandang tunanetra. Mencakup model interaksi untuk menangani masukan (input) dan keluaran (output) pada aplikasi.
4. Antarmuka yang sesuai untuk penyandang tunanetra.

5. Game play yang sesuai untuk pembelajaran aritmatika bagi penyandang tunanetra.

\subsection{Perancangan (Design)}

Berdasarkan hasil diskusi dengan beberapa guru di SLB Yaketunis, maka aplikasi pada penelitian ini akan dibangun sebagai aplikasi berbasis Android yang dijalankan pada perangkat bergerak. Materi yang diangkat pada penelitian ini adalah materi operasi bilangan dasar dengan hasil perhitungan maksimal 50 untuk siswa kelas 4, hasil perhitungan maksimal 99 untuk siswa kelas 5, dan hasil perhitungan maksimal 99 dalam bentuk soal cerita untuk siswa kelas 6. Pada proses interaksi, perangkat masukan (input) yang akan digunakan pada aplikasi adalah layar sentuh (touchscreen) yang ada pada ponsel pintar. Layar sentuh pada ponsel pintar berbasis Android dapat menerima masukan dalam bentuk sentuhan tunggal (touch), sentuh dan tahan (hold), geser (swipe), serta multi sentuhan (multitouch).

Pada penelitian ini layar sentuh akan berfungsi untuk menerima masukan dalam bentuk sentuhan tunggal dan geser. Sentuhan tunggal digunakan untuk mengetahui jenis tombol pilihan, sedangkan geser untuk mengaktifkan tombol. Pada perangkat keluaran (output), aplikasi ini akan memanfaatkan layar pada ponsel pintar untuk tampilan visual. Tampilan visual akan dibuat dalam 3 warna, yaitu merah, biru, dan putih. 
Tabel 1. Penjelasan VTOC

\begin{tabular}{c|l}
\hline PROSES & \multicolumn{1}{c}{ KETERANGAN } \\
\hline DGBL & $\begin{array}{l}\text { Proses ini adalah proses pertama yang dijalankan saat aplikasi ini dimulai. } \\
\text { Pada proses pertama ini, pemain akan diarahkan untuk memilih dua } \\
\text { pilihan yang ada pada menu utama, yaitu Permainan dan Petunjuk. }\end{array}$ \\
0.0 & $\begin{array}{l}\text { Proses permainan adalah proses yang dijalankan untuk memulai } \\
\text { permainan pada aplikasi ini. Pada proses ini pemain akan memilih tingkat } \\
\text { permainan yang terdiri tingkat mudah, sedang, dan sulit. Petunjuk } \\
\text { pemilihan tingkat disampaikan dalam bentuk narasi suara. }\end{array}$ \\
1.0 & $\begin{array}{l}\text { Proses petunjuk adalah proses yang dijalankan untuk menampilkan } \\
\text { petunjuk permainan pada aplikasi ini. Petunjuk permainan disampaikan } \\
\text { dalam bentuk narasi suara. Untuk dapat kembali pada proses sebelumnya, } \\
\text { pemain cukup menyentuh layar diposisi manapun. }\end{array}$ \\
Petunjuk & $\begin{array}{l}\text { Proses mudah adalah proses yang dijalankan apabila pemain memilih } \\
\text { tingkat permainan mudah. Pada proses ini model permainan akan } \\
\text { dimainkan oleh para pemain. Tingkat permainan mudah menampilkan } \\
\text { soal operasi matematika dasar dengan hasil perhitungan maksimal } \\
\text { bernilai 50. } \\
\text { Proses mudah adalah proses yang dijalankan apabila pemain memilih } \\
\text { tingkat permainan mudah. Pada proses ini model permainan akan } \\
\text { dimainkan oleh para pemain. Tingkat permainan sedang menampilkan } \\
\text { soal operasi matematika dasar dengan hasil perhitungan maksimal } \\
\text { bernilai 99. } \\
\text { Proses mudah adalah proses yang dijalankan apabila pemain memilih } \\
\text { tingkat permainan mudah. Pada proses ini model permainan akan } \\
\text { dimainkan oleh para pemain. Tingkat permainan sulit menampikan soal } \\
\text { operasi matematika dasar dengan hasil perhitungan maksimal bernilai 99 } \\
\text { dalam bentuk soal cerita (analisis kasus). }\end{array}$ \\
Sedang & $\begin{array}{c}\text { Sulit } \\
1.2\end{array}$
\end{tabular}

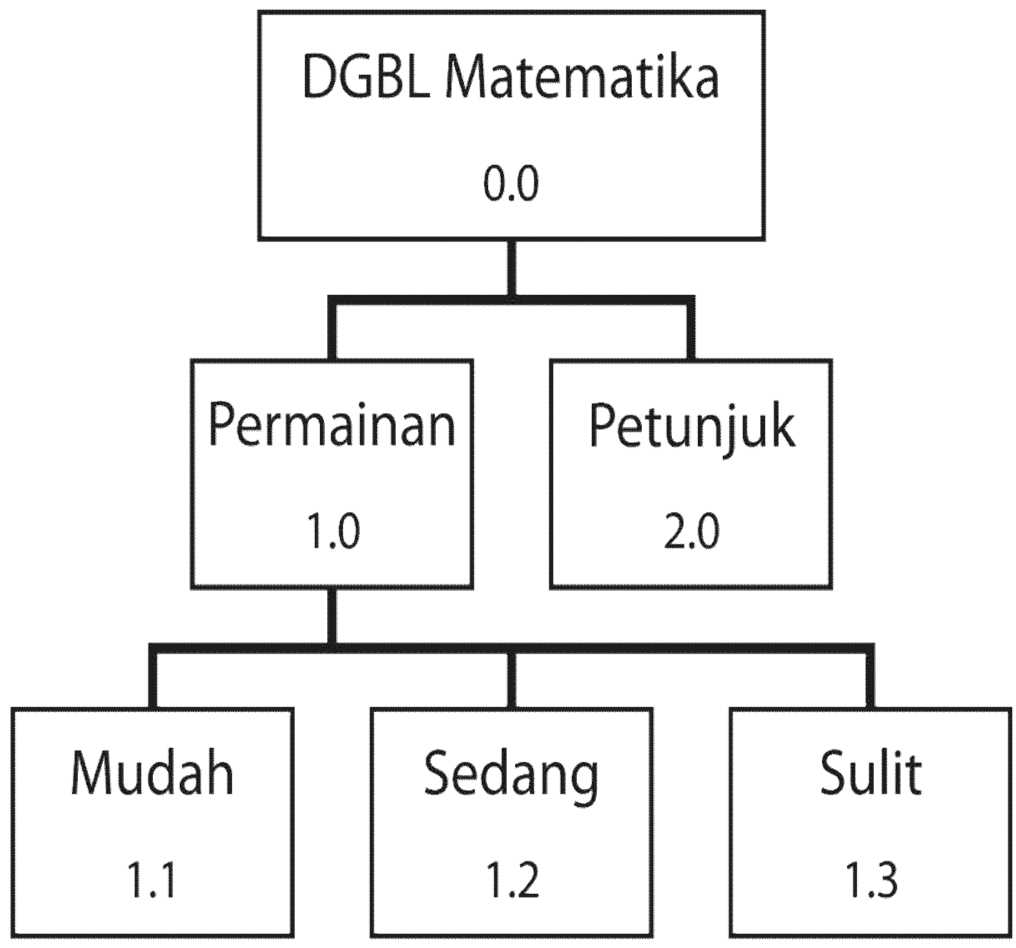

Gambar 1. VTOC. 
Sedangkan informasi soal akan disampaikan melalui perangkat keluaran pengeras suara (speaker) dalam bentuk suara narasi. Untuk memudahkan proses pengembangan aplikasi, maka aplikasi akan dikembangkan dengan metode perancangan HIPO (Hierarchy plus Input Process Output) untuk fungsional sistem dan perancangan antarmuka untuk visualisasi sistem. HIPO terdiri dari 3 tingkatan, yaitu VTOC (Visual Tabel of Content), Diagram Ringkas (Overview Diagram), dan Diagram Detail (Detail Diagram). VTOC yang dibuat terdiri dari 5 proses utama, yaitu Mulai, Petunjuk, Mudah, Sedang, dan Sulit. VTOC dari aplikasi yang dikembang dapat dilihat pada gambar 1, sedangkan penjelasan dari tiap prosesnya dapat dilihat pada tabel 1 .
Untuk menyederhanaan proses penulisan makalah, rancangan diagarm detail tidak akan ditampilkan karena sangat spesifik sesuai dengan bahasa pemrograman yang digunakan. Selain itu, hasil rancangan diagram ringkas juga akan disampaikan sesuai rancangan antarmuka yang digunakan pada tiap proses.

\section{Proses Utama}

Proses utama terdiri dari satu halaman, yaitu halaman utama dengan rancangan antarmuka seperti pada Gambar 2(a). Rancangan tersebut terdiri dari 3 (tiga) tombol utama, yaitu tombol permainan, tombol pertunjuk, dan tombol keluar. Semua tombol dalam aplikasi dibuat dalam 2 (dua) bentuk interaksi, yaitu sentuh (touch) dan geser (swipe). Diagram ringkas halaman utama dapat dilihat pada gambar 3 .
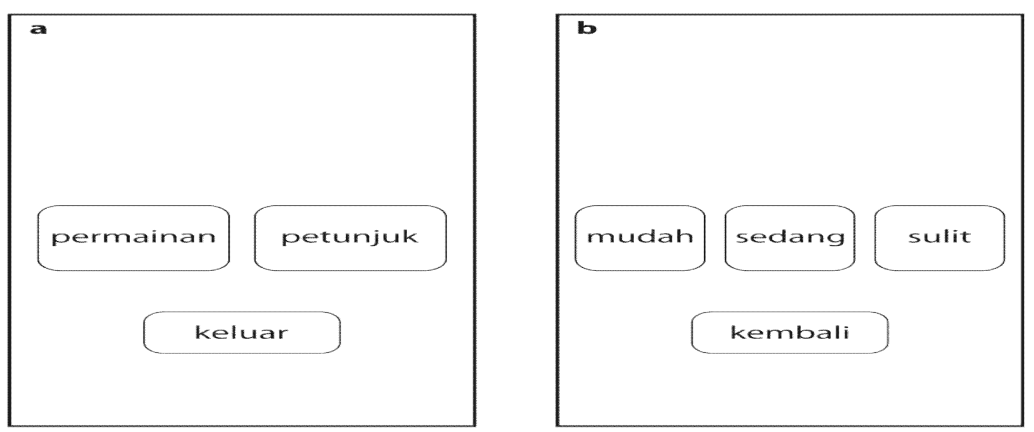

Gambar 2. a.Rancangan Antarmuka Halaman Utama, b.Rancangan Antarmuka Halaman Pilih Tingkatan.

\begin{tabular}{|c|c|c|}
\hline input & process & output \\
\hline $\begin{array}{c}\text { halaman menu utama } \\
\text { terbuka }\end{array}$ & $\begin{array}{l}\text { memutar narasi } \\
\text { "arahan menu utama" }\end{array}$ & $\begin{array}{l}\text { suara narasi } \\
\text { "arahan menu utama" }\end{array}$ \\
\hline $\begin{array}{l}\text { sentuh tombol } \\
\text { permainan }\end{array}$ & $\begin{array}{l}\text { memutar narasi } \\
\text { "permainan" }\end{array}$ & $\begin{array}{l}\text { suara narasi } \\
\text { "permainan" }\end{array}$ \\
\hline $\begin{array}{l}\text { geser tombol } \\
\text { permainan }\end{array}$ & $\begin{array}{l}\text { pindah ke halaman } \\
\text { pilih tingkatan }\end{array}$ & $\begin{array}{l}\text { tampil halaman } \\
\text { pilih tingkatan }\end{array}$ \\
\hline $\begin{array}{l}\text { sentuh tombol } \\
\text { petunjuk }\end{array}$ & $\begin{array}{l}\text { memutar narasi } \\
\text { "petunjuk" }\end{array}$ & $\begin{array}{l}\text { suara narasi } \\
\text { "petunjuk" }\end{array}$ \\
\hline $\begin{array}{l}\text { geser tombol } \\
\text { petunjuk }\end{array}$ & $\begin{array}{c}\text { pindah ke halaman } \\
\text { petunjuk }\end{array}$ & $\begin{array}{l}\text { tampil halaman } \\
\text { petunjuk }\end{array}$ \\
\hline $\begin{array}{l}\text { sentuh tombol } \\
\text { keluar }\end{array}$ & $\begin{array}{c}\text { memutar narasi } \\
\text { "keluar" }\end{array}$ & $\begin{array}{l}\text { suara narasi } \\
\text { "keluar" }\end{array}$ \\
\hline $\begin{array}{l}\text { geser tombol } \\
\text { keluar }\end{array}$ & menutup aplikasi & keluar aplikasi \\
\hline
\end{tabular}

Gambar 3. Diagram Ringkas Halaman Utama. 


\section{Proses Permainan}

Proses permainan terbagi menjadi 3 (tiga) tampilan halaman, yaitu halaman pilih tingkatan, halaman permainan dan halaman skor akhir. Halaman pilih tingkatan dapat dilihat pada gambar 2 (b), sedangkan halaman permainan serta halaman skor akhir dapat dilihat pada gambar 4 .
Halaman pilih tingkatan terdiri dari tombol - tombol yang mewakili tiap tingkat kesulitan, yaitu mudah, sedang, dan sulit. Selain itu juga terdapat tombol kembali yang dapat digunakan untuk kembali ke halaman utama. Diagram ringkas halaman pilih tingkatan dapat dilihat pada gambar 5.
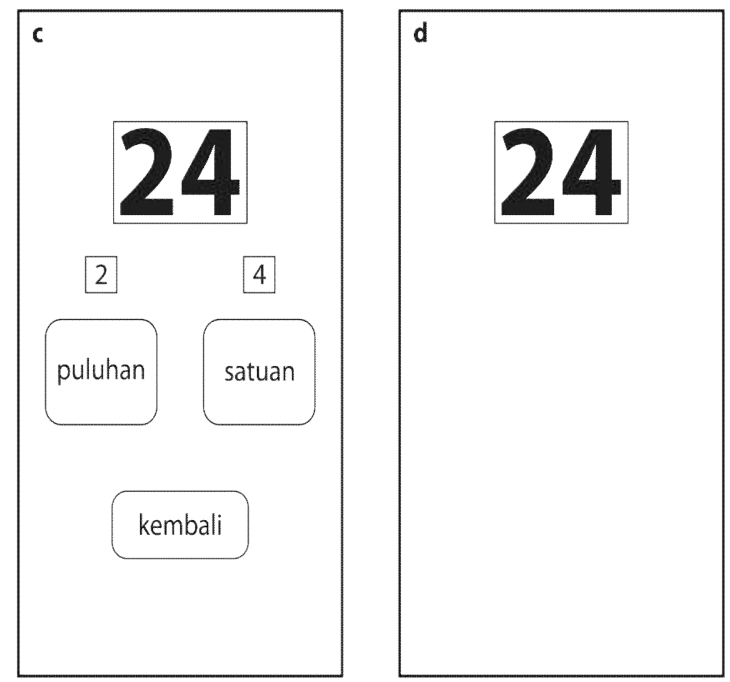

Gambar 4 c. Rancangan Antarmuka Halaman Permainan, d.Rancangan Antarmuka Halaman Skor Akhir.

\begin{tabular}{|c|c|c|}
\hline input & process & output \\
\hline $\begin{array}{l}\text { halaman pilih } \\
\text { tingkatan terbuka }\end{array}$ & $\begin{array}{l}\text { memutar narasi } \\
\text { "arahan pilih tingkatan" }\end{array}$ & $\begin{array}{c}\text { suara narasi } \\
\text { "arahan pilih tingkatan" }\end{array}$ \\
\hline $\begin{array}{l}\text { sentuh tombol } \\
\text { mudah }\end{array}$ & $\begin{array}{l}\text { memutar narasi } \\
\text { "mudah" }\end{array}$ & $\begin{array}{l}\text { suara narasi } \\
\text { "permainan" }\end{array}$ \\
\hline $\begin{array}{l}\text { geser tombol } \\
\text { mudah }\end{array}$ & $\begin{array}{l}\text { pindah ke halaman } \\
\text { permainan mudah }\end{array}$ & $\begin{array}{l}\text { tampil halaman } \\
\text { permainan mudah }\end{array}$ \\
\hline $\begin{array}{l}\text { sentuh tombol } \\
\text { sedang }\end{array}$ & $\begin{array}{l}\text { memutar narasi } \\
\text { "sedang" }\end{array}$ & $\begin{array}{l}\text { suara narasi } \\
\text { "sedang" }\end{array}$ \\
\hline $\begin{array}{l}\text { geser tombol } \\
\text { sedang }\end{array}$ & $\begin{array}{l}\text { pindah ke halaman } \\
\text { permainan sedang }\end{array}$ & $\begin{array}{c}\text { tampil halaman } \\
\text { permainan sedang }\end{array}$ \\
\hline $\begin{array}{l}\text { sentuh tombol } \\
\text { sulit }\end{array}$ & $\underset{\text { memutar narasi }}{\text { "sulit" }}$ & $\begin{array}{l}\text { suara narasi } \\
\text { "sulit" }\end{array}$ \\
\hline $\begin{array}{l}\text { geser tombol } \\
\text { sulit }\end{array}$ & $\begin{array}{l}\text { pindah ke halaman } \\
\text { permainan sulit }\end{array}$ & $\begin{array}{l}\text { tampil halaman } \\
\text { permainan sulit }\end{array}$ \\
\hline $\begin{array}{l}\text { sentuh tombol } \\
\text { kembali }\end{array}$ & $\begin{array}{l}\text { memutar narasi } \\
\text { "kembali" }\end{array}$ & $\begin{array}{l}\text { suara narasi } \\
\text { "kembali" }\end{array}$ \\
\hline $\begin{array}{l}\text { geser tombol } \\
\text { kembali }\end{array}$ & $\begin{array}{l}\text { pindah ke halaman } \\
\text { menu utama }\end{array}$ & $\begin{array}{l}\text { tampil halaman } \\
\text { menu utama }\end{array}$ \\
\hline
\end{tabular}

Gambar 5. Diagram Ringkas Halaman Pilih Tingkatan. 
Pada saat pemain memilih tingkat kesulitan mudah, maka aplikasi akan mengerjakan proses mudah, begitupun ketika pemain memilih tingkat kesulitan sedang atau sulit, maka aplikasi akan mengerjakan proses sedang atau sulit. Tampilan halaman pada proses mudah, sedang, dan sulit memiliki kesamaan visual dan fungsional, yang membedakan hanya jenis soal yang akan ditampilkan (sesuai dengan tabel penjelasan proses VTOC).

Halaman permainan terdiri dari tombol kembali untuk kembali ke halaman sebelumnya, tombol puluhan, dan tombol satuan. Tombol puluhan dan satuan merupakan tombol yang digunakan untuk membuat suatu jawaban berupa bilangan 1 sampai 99. Untuk membuat bilangan 24, maka pemain harus menekan tombol puluhan sebanyak 2 kali $(1,2)$ dan tombol satuan sebanyak 4 kali $(1,2,3$, 4). Tiap tombol dimulai dari angka 0 dan berakhir di angka 9, setelah mencapai angka 9, maka akan kembali ke angka 0. Diagram ringkas halaman pilih tingkatan dapat dilihat pada gambar 6.

Tidak terdapat tombol pada halaman skor akhir. Hanya terdapat satu interaksi pada halaman ini, yaitu menyentuh layar. Ketika pemain menyentuh layar, maka pemain akan kembali pada halaman utama. Diagram ringkas halaman skor akhir dapat dilihat pada gambar 7 .

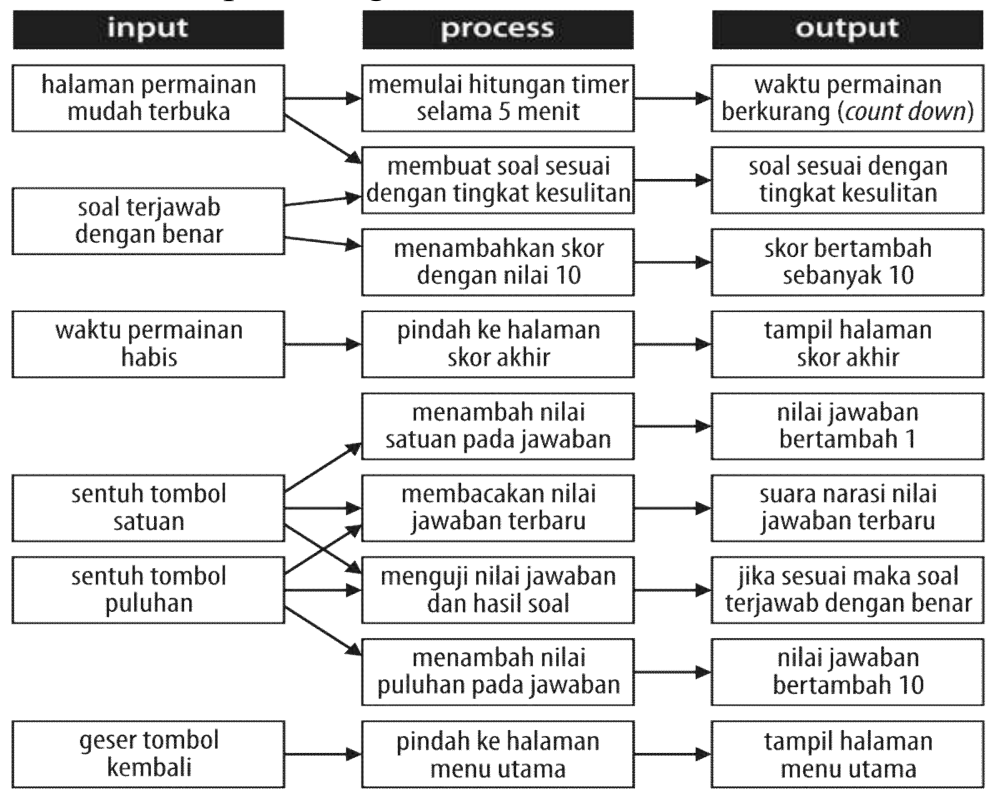

Gambar 6. Diagram Ringkas Halaman Permainan.

\begin{tabular}{|c|c|c|}
\hline input & process & output \\
\hline $\begin{array}{c}\text { halaman skor akhir } \\
\text { terbuka }\end{array}$ & $\begin{array}{l}\text { membacakan nilai } \\
\text { skor akhir }\end{array}$ & $\begin{array}{c}\text { suara narasi } \\
\text { nilai skor akhir }\end{array}$ \\
\hline sentuh layar & $\begin{array}{l}\text { kembali ke halaman } \\
\text { menu utama }\end{array}$ & $\begin{array}{l}\text { tampil halaman } \\
\text { menu utama }\end{array}$ \\
\hline
\end{tabular}

Gambar 7. Diagram Ringkas Halaman Skor Akhir.

\section{Proses Petunjuk}

\begin{tabular}{|c|c|c|}
\hline input & process & output \\
\hline $\begin{array}{c}\text { halaman petunjuk } \\
\text { terbuka }\end{array}$ & $\begin{array}{l}\text { memutar narasi } \\
\text { "arahan permainan" }\end{array}$ & $\begin{array}{c}\text { suara narasi } \\
\text { "arahan permainan" }\end{array}$ \\
\hline sentuh layar & $\begin{array}{l}\text { kembali ke halaman } \\
\text { menu utama }\end{array}$ & $\begin{array}{l}\text { tampil halaman } \\
\text { menu utama }\end{array}$ \\
\hline
\end{tabular}

Gambar 8. Diagram Ringkas Halaman Petunjuk. 
Proses petunjuk hanya terdiri dari halaman petunjuk. Pada halaman petunjuk tidak terdapat tampilan apapun. Informasi petunjuk permainan disampaikan dengan menggunakan suara narasi. Untuk kembali ke halaman awal, pemain cukup menyentuh layar. Diagram ringkas halaman petunjuk dapat dilihat pada Gambar 8 .

\subsection{Pengembangan (Development)}

Aplikasi dikembangkan menggunakan perangkat lunak Adobe Air dengan bahasa pemrograman ActionScript 3.0. Aplikasi ini hanya menggunakan 3 warna dasar, yaitu putih, merah tua dan biru tua. Penggunaan

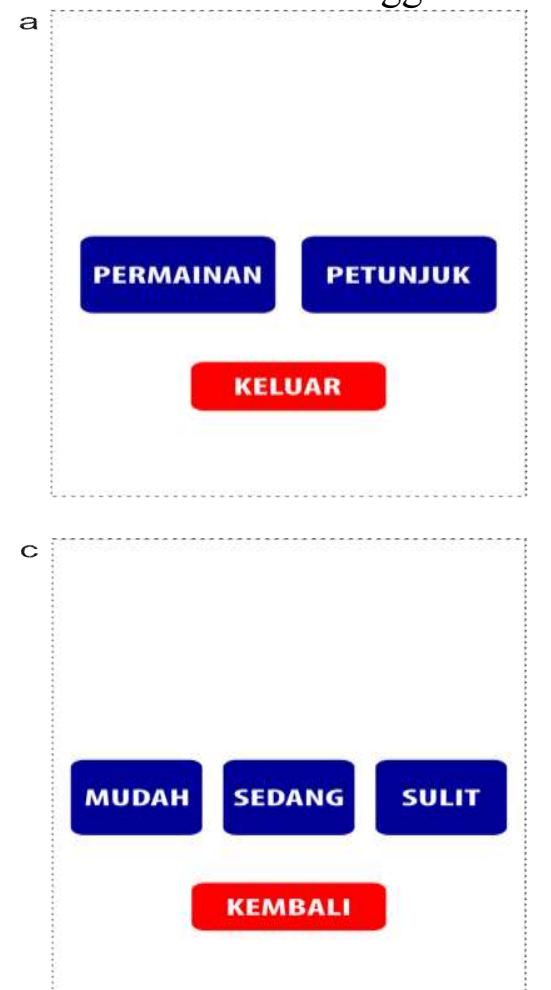

warna merah tua dan biru tua harus berada diatas warna putih (kontras). Penggunaan warna merah dan biru ditujukan untuk memberikan pembeda pada pengelompokan tombol yang ada pada aplikasi. Untuk memperjelas batas gambar, maka garis putus-putus ditambahkan pada bagian tepi gambar. Antarmuka halaman utama dapat dilihat pada gambar 9Gambar 9 (a), antarmuka halaman petunjuk dapat dilihat pada Gambar 9 (b), antarmuka halaman pilih tingkatan dapat dilihat pada Gambar 9 (c), sedangkan antarmuka halaman permainan dapat dilihat pada Gambar 9 (d).

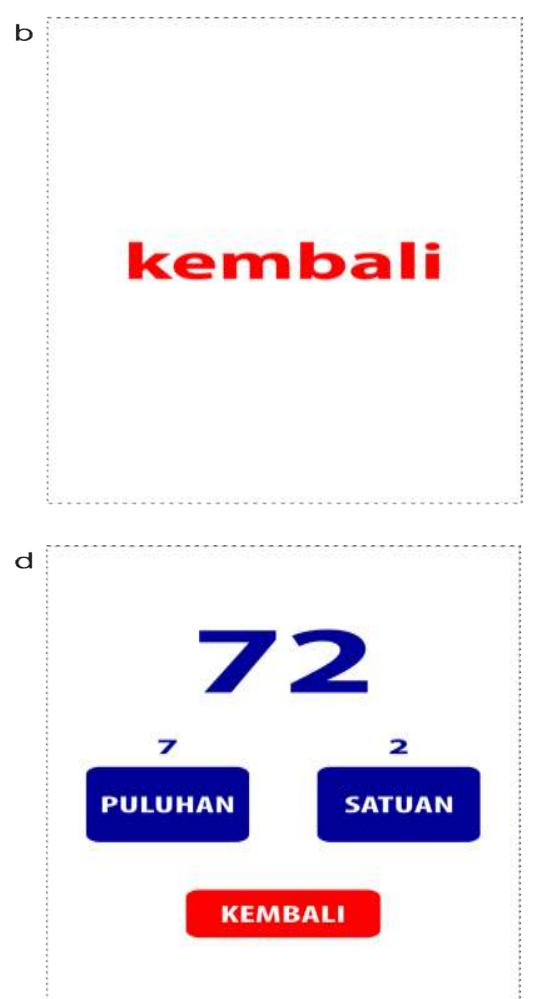

Gambar 9.a. Antarmuka Halaman Utama, b. Antarmuka Halaman Petunjuk, c. Antarmuka Halaman Pilih Tingkatan, d.Antarmuka Halaman Permainan.

\section{SKOR 140}

Gambar 10. Antarmuka Halaman Skor Akhir. 
Skor akhir akan ditampilkan setelah para pemain menyelesaikan satu sesi permainan. Skor ditampilkan dalam bentuk angka dan narasi suara. Antarmuka halaman skor akhir dapat dilihat pada gambar 10 .

\subsection{Implementasi (Implementation)}

Proses implementasi dilaksanakan setelah aplikasi selesai dikerjakan dan siap untuk digunakan. Proses implementasi dilakukan dalam 2 (dua) tahap, yaitu tahap implementasi terhadap tenaga pengajar (guru) dan implementasi terhadap pembelajar (siswa). Dua tahapan tersebut harus dilaksanakan secara berurutan, dimulai dari tahap implementasi terhadap tenaga pengajar dan dilanjutkan dengan tahap implementasi terhadap pembelajar.

\subsection{Implementasi Terhadap Tenaga Pengajar}

Implementasi terhadap tenaga pengajar dilakukan untuk mengetahui apakah aplikasi yang telah dibangun telah sesuai untuk digunakan terhadap pembelajar. Para tenaga pengajar akan memastikan konten materi yang dibuat telah sesuai dengan kurikulum yang diajarkan dan bentuk interaksi telah sesuai dengan kemampuan interaksi para pembelajar. Proses implementasi terhadap tenaga pengajar melibatkan 6 (enam) guru SLB Yaketunis. Untuk dapat memberikan umpan balik yang lebih obyektif dan orisinil, keenam guru tersebut melalui sesi uji coba aplikasi pada waktu yang berbeda (tidak dalam satu waktu).
Proses implementasi dilakukan dengan memberikan kesempatan kepada para responden untuk menggunakan aplikasi dalam selang waktu tertentu, kemudian para responden melakukan penilaian terkait fitur yang disajikan dalam permainan berdasarkan pengalaman saat menggunakan aplikasi tersebut. Aspek penilaian yang digunakan adalah :

1. Daya tarik aplikasi bagi pengguna.

2. Kemudahan fungsi tombol.

3. Kejelasan suara narasi.

4. Kesesuaian konten dengan kurikulum.

5. Kemampuan menghindari kesalahan pengguna.

Supaya memudahkan proses pengisian kuesioner, kelima aspek tersebut diturunkan menjadi pernyataan sebagai berikut :

1. Aplikasi menarik dan telah sesuai untuk dimainkan oleh siswa.

2. Tombol yang ada mudah dikenali fungsinya dan mudah diakses.

3. Narasi terkait cara penggunaan sudah cukup jelas.

4. Narasi terkait soal sudah cukup jelas.

5. Soal yang ditampilkan sesuai dengan kemampuan para siswa.

6. Saya tidak mengalami kesalahan dalam penggunaan aplikasi ini.

Sesi implementasi terhadap salah seorang responden dapat dilihat pada gambar 11 .

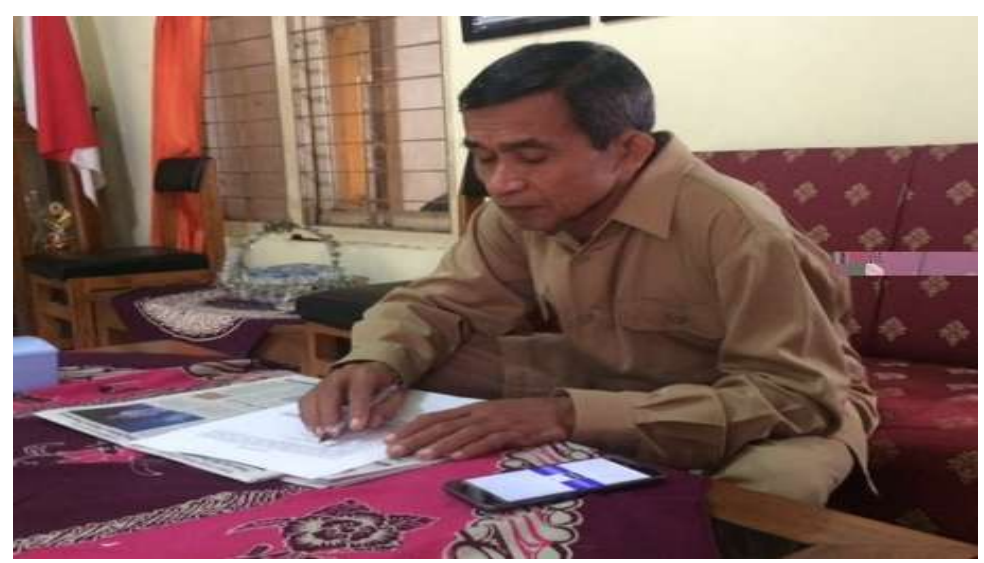

Gambar 11. Implementasi Terhadap Tenaga Pengajar. 
Tabel 2. Persentase Bobot

\begin{tabular}{c|c}
\hline PERSENTASE & KETERANGAN \\
\hline $0 \%-19.99 \%$ & Sangat Tidak Setuju \\
$20 \%-39.99 \%$ & Tidak Setuju \\
$40 \%-59.99 \%$ & Netral / Ragu - ragu \\
$60 \%-79.99 \%$ & Setuju \\
$80 \%-100 \%$ & Sangat Setuju \\
\hline
\end{tabular}

Tabel 3. Hasil Kuesioner Tenaga Pengajar

\begin{tabular}{c|c|c|c}
\hline NO & PERNYATAAN & TOTAL & PERSEN \\
\hline 1 & $\begin{array}{c}\text { Aplikasi menarik dan telah sesuai untuk dimainkan } \\
\text { oleh siswa }\end{array}$ & 17 & $70.83 \%$ \\
2 & $\begin{array}{c}\text { Tombol yang ada mudah dikenali fungsinya dan } \\
\text { mudah diakses }\end{array}$ & 15 & $62.50 \%$ \\
3 & $\begin{array}{c}\text { Narasi terkait cara penggunaan sudah cukup jelas } \\
4\end{array}$ & 17 & $70.83 \%$ \\
5 & $\begin{array}{c}\text { Noarasi terkait soal sudah cukup jelas } \\
\text { para siswa }\end{array}$ & 18 & $75.00 \%$ \\
6 & $\begin{array}{c}\text { Saya tidak mengalami kesalahan dalam penggunaan } \\
\text { aplikasi ini }\end{array}$ & 11 & $75.00 \%$ \\
\hline
\end{tabular}

\subsection{Implementasi Terhadap Pembelajar}

Implementasi terhadap pembelajar dilakukan dengan menggunakan metode wawancara. Metode wawancara dipilih karena kemudahannya untuk menghimpun tanggapan dari pembelajar terhadap aplikasi yang mereka gunakan. Proses implementasi terhadap pembelajar melibatkan siswa penyandang tunanetra pada jenjang kelas 4 sampai 6 yang dinilai masih cukup relevan untuk mendapatkan materi terkait dengan aritmatika dasar.

Proses implementasi dilakukan dengan memberikan kesempatan kepada para pembelajar untuk menggunakan aplikasi dalam selang waktu tertentu, lalu kemudian dilakukan proses wawancara sesuai dengan aspek penilaian yang ditentukan.
Aspek penilaian yang digunakan lebih sederhana dari aspek penilaian yang digunakan terhadap tenaga pengajar. Aspek penilaian yang digunakan adalah :

1. Daya tarik aplikasi bagi pengguna.

2. Manfaat aplikasi bagi pengguna.

3. Kemudahan fungsi tombol.

4. Kejelasan suara narasi.

5. Kemampuan menghindari kesalahan.

Proses pengambilan kesimpulan pada proses wawancara dilakukan dengan cara mengkombinasikan tanggapan dari masingmasing responden. Sesi implementasi yang dilakukan terhadap pembelajar dapat dilihat pada gambar 12 . 


\subsection{Evaluasi (Evaluation)}

Proses penilaian oleh tenaga pengajar dilakukan dengan memberikan bobot penilaian (dalam skala likert) terhadap masing - masing aspek. Bobot yang digunakan adalah sebagai berikut :

1. Bobot nilai 0 untuk jawaban Sangat Tidak Setuju (STS).

2. Bobot nilai 1 untuk jawaban Tidak Setuju (TS).

3. Bobot nilai 2 untuk jawaban netral/raguragu $(\mathrm{N})$.

4. Bobot nilai 3 untuk jawaban Setuju (S).

5. Bobot nilai 4 untuk jawaban Sangat Setuju (SS).

Nilai terendah untuk skala tersebut adalah 0 (jumlah responden $\mathrm{x}$ bobot terendah), sedangkan nilai tertingginya adalah 24 (jumlah responden $\mathrm{x}$ bobot tertinggi). Skala persentase untuk tiap bobot dapat dilihat pada Tabel 2. Dari hasil pengujian yang dilakukan terhadap tenaga pengajar didapatkan hasil pengisian kuesioner seperti pada Tabel 3.

Dari hasil kuesioner tersebut para responden setuju terhadap pernyataan berikut :
1. Aplikasi menarik dan telah sesuai untuk dimainkan oleh siswa.

2. Tombol yang ada mudah dikenali fungsinya dan mudah diakses.

3. Narasi terkait cara penggunaan sudah cukup jelas.

4. Narasi terkait soal sudah cukup jelas.

5. Soal yang ditampilkan sesuai dengan kemampuan para siswa.

Selain itu para responden memilih netral / ragu - ragu terhadap pernyataan "Saya tidak mengalami kesalahan dalam penggunaan aplikasi ini".

Proses evaluasi oleh pembelajar dilakukan dengan menggunakan metode wawancara terhadap aspek penilaian yang telah ditentukan sebelumnya. Hasil wawancara yang didapat kemudian disimpulkan menjadi beberapa kesimpulan sebagai berikut :

1. Aplikasi ini mampu mengasah kemampuan siswa dalam proses pembelajaran aritmatika.

2. Aplikasi ini merupakan sarana baru yang inovatif untuk pembelajaran aritmatika di SLB Yaketunis.

3. Aplikasi ini dapat dimainkan kapanpun dan dimanapun.

4. Tombol terlalu kecil (kurang besar).

5. Suara yang dikeluarkan sudah informatif namun masih kurang jernih.

6. Perlu menggunakan fasilitas getar (vibrasi) untuk memudahkan interaksi.

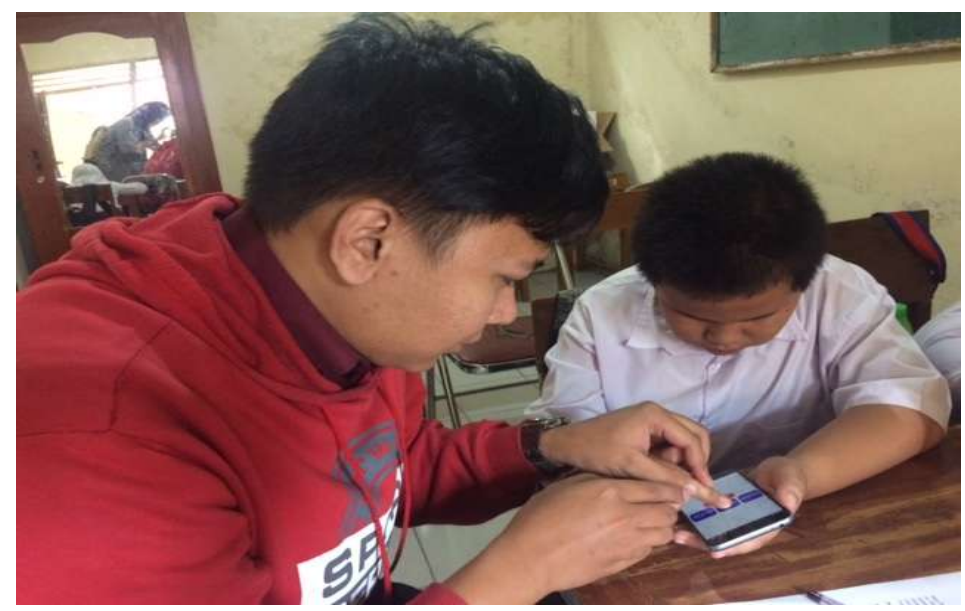

Gambar 12. Implementasi Terhadap Pembelajar. 


\section{KESIMPULAN}

Aplikasi Digital Game Based Learning untuk proses pembelajaran aritmatika telah dibangun sesuai dengan perancangan yang disusun berdasarkan kebutuhan pengguna di SLB Yaketunis. Aplikasi yang dibangun cukup mudah untuk diterima karena sederhana dan menarik serta mudah untuk digunakan. Kemudahan aplikasi yang dikembangkan dapat dilihat dari kejelasan bahasa instruksi yang disampaikan dalam bentuk narasi serta tidak banyaknya tombol yang ada pada tiap tampilan. Banyaknya tombol pada suatu tampilan dapat meningkatkan jumlah interaksi dan menyulitkan para pengguna untuk melakukan suatu aksi. Kendati demikian, kualitas suara narasi masih perlu ditingkatkan karena dari hasil wawancara masih ditemukan tanggapan terkait kualitas kejernihan suara yang dikeluarkan oleh aplikasi. Penggunaan tombol juga masih perlu mendapat perhatian, dari hasil wawancara didapat bahwa tombol masih terlalu kecil untuk dapat diakses, selain itu bentuk interaksi terhadap tombol juga masih perlu dikembangkan. Penggunaan teknik sentuh (touch) dan geser (swipe) pada tombol berpotensi menimbulkan kesalahan dalam penggunaan aplikasi ini.

\section{Diskusi}

Penggunaan aplikasi pada ponsel pintar (smart phone) berbasis Android tidak menyulitkan para siswa di SLB Yaketunis, hal tersebut dapat dijadikan sebagai acuan untuk pengembangan aplikasi - aplikasi sejenis yang lebih inovatif. Penggunaan tombol pada aplikasi yang dibuat pada penelitian ini dinilai masih terlalu kecil untuk diakses.
Aplikasi ini dibangun dengan menggunakan orientasi potret (portrait) untuk memudahkan para pengguna dalam menggenggam perangkat bergerak yang digunakan. Optimalisasi tombol dapat dimaksimalkan dengan merubah orientasi layar menjadi lanskap (landscape) dengan pertimbangan penggunaan ponsel pintar menggunakan kedua tangan.

Kesalahan penggunaan yang terjadi akibat penerapan teknik sentuh (touch) dan geser (swipe) dapat dikembangkan dengan menggunakan bentuk interaksi lain seperti tahan (hold) atau klik dua kali (double click). Interakasi tombol juga dapat dipadukan dengan fasilitas vibrasi untuk dapat memberikan umpan balik terhadap suatu aksi yang dilakukan oleh pengguna.

\section{DAFTAR PUSTAKA}

Ali, A., Peng, L.S., Sujardi, I., Usodo, B. and Perdana, F.A. Six to Ten Digits Multiplication Fun Learning Using Puppet Prototype. Journal of Physics : Conference Series, 795(1), pp.012003. IOP Publishing., 2017.

Berger, S. and Porell, F. The Association Between Low Vision And Function. Journal of Aging and Health, 20(5), pp.504-525., 2008.

Heuten, W., Henze, N., Boll, S. and Pielot, M. Tactile wayfinder: a non-visual support system for wayfinding. Proceedings of the 5th Nordic conference on Human-computer interaction : building bridges, pp.172-181. ACM., 2008.

Huang, S. T., Cho, Y. P., \& Lin, Y. J. ADDIE instruction design and cognitive apprenticeship for projectbased software engineering education in MIS. Software Engineering Conference, APSEC'05, 12th Asia - Pacific. IEEE., 2005. 
Hussain, S.Y.S., Tan, W.H. and Idris, M.Z. Digital Game - Based Learning For Remedial Mathematics Students: A New Teaching And Learning Approach In Malaysia. International Journal of Multimedia Ubiquitous Engineering, 9 (11), pp.325-338., 2014.

Jonas, J.B., Bourne, R.R., White, R.A., Flaxman, S.R., Keeffe, J., Leasher, J., Naidoo, K., Pesudovs, K., Price, H., Wong, T.Y. and Resnikoff, S. Visual Impairment And Blindness Due To Macular Diseases Globally: A Systematic Review And MetaAnalysis. American journal of ophthalmology, 158(4), pp.808815., 2014.

Jonsson, B., Norqvist, M., Liljekvist, Y. and Lithner, J. Learning Mathematics Through Algorithmic And Creative Reasoning. The Journal of Mathematical Behavior, 36, pp.2032., 2014.

Kanyemba, T., Peters, A. and Jere, N. Universal Design (UD) And Visual Impairment: Can UD Principles Be Applied For Mobile Sharing Platform?. IST-Africa Week Conference (IST-Africa), pp.1-8. IEEE., 2017.
Kolb, A.Y. and Kolb, D.A. Learning styles and learning spaces: Enhancing experiential learning in higher education. Academy of management learning \& education, 4 (2), pp.193-212., 2005.

Kordestani, F., Daneshfar, A. and Roustaee, D. Comparison of Qualityo of Life And Social Skills Between Students With Visual Problems (Blind And Partially Blind) And Normal Students. International Journal of Academic Research in Progressive Education and Development, 3(4), pp.384-391., 2014.

La Guardia, D., Gentile, M., Dal Grande, V., Ottaviano, S. and Allegra, M.. A game based learning model for entrepreneurship education. Procedia-Social and Behavioral Sciences, 141, pp.195-199, 2014.

Mahardhika, G.P. Math Ship: Digital Game Based Learning to Improve Students' Mathematics Skill. Advanced Science Letters, 22 (10), pp.3181-3184., 2016.

McAllister, R. and Gray, C. Low vision: mobility and independence training for the early years child. Early Child Development and Care, 177(8), pp.839-852., 2007. 
Sarabandi, A., Kamali, M. and Mobaraki, H. The Relationship Between Impaired Visual Function And Quality of Life of The Blind. Journal of Research in Rehabilitation Sciences, 8(6), pp.1015-1023., 2013.

Söveny, B., Kovács, G. and Kardkovács, Z.T. Blind Guide-A Virtual Eye For Guiding Indoor And Outdoor Movement. Cognitive Info Communications ( CogInfoCom ), 5th IEEE Conference, pp.343-347. IEEE., 2014.

Tang, W. L., Tsai, J. T., \& Chen, C. H. Research on ADDIE model applied to develop the digital material of MCRLC in Taiwan. Society of Instrument and Control Engineers of Japan (SICE), 2017 56th Annual Conference of the, pp. 561-563. IEEE., 2017.

Vogel, S.A., Leyser, Y., Wyland, S. and Brulle, A. Students with learning disabilities in higher education: Faculty attitude and practices. Learning Disabilities Research \& Practice, 14(3), pp.173-186., 1999. 